\title{
Eportfolio in Ireland: A landscape snapshot of current practice
}

\author{
Orna Farrell ${ }^{* 1}$ \\ Karen Buckley ${ }^{2}$ \\ Lisa Donaldson ${ }^{3}$ \\ Tom Farrelly ${ }^{4}$ \\ ${ }^{1}$ Dublin City University \\ ${ }^{2}$ Dublin City University \\ ${ }^{3}$ Dublin City University \\ ${ }^{4}$ Munster Technological University
}

\section{Abstract}

This article reports on a study that explored eportfolio practice in Irish higher education. The aim of this research was to gain a landscape snapshot of eportfolio practice and technologies across Irish Higher Education Institutes (HEI) and to address a gap in the literature that there is little empirical evidence about how Irish HEIs engage and adopt eportfolio in practice. The project adopted a mixed method approach and was framed by two research questions: $R Q 1$ : What are the features of eportfolio practice in Irish higher education? RQ2: What are the experiences of Irish higher education practitioners in adopting eportfolio? Data was collected from seventy-nine participants from a range of Irish HEIs using an anonymous online survey. The four central themes that make up the study's findings highlight key issues related to institutional engagement with eportfolio including features of eportfolio practice; technology underpinning eportfolio practice; enablers of eportfolio adoption and barriers to eportfolio adoption. The findings of this study indicate that Irish teaching staff use eportfolios with their students primarily for assessment, reflection, to support placement experiences and to develop student employability skills. There was also evidence that staff are using eportfolios for personal and/or professional purposes. Furthermore, it is particularly noteworthy that hardly anyone in the study reported evaluating their eportfolio practice. In addition, our findings indicate that the implementation and adoption of eportfolio by Irish HEIs has been quite uneven, the majority of institutions were reported to be at the early stages of adoption. While this study provides useful insight regarding the institutional and staff perspective, the research team do acknowledge that the student voice was not captured in this instance.

\section{Introduction}

This article reports on an investigation into the engagement and adoption of eportfolio practice in Irish higher education. Specifically, the aim of this research to gain a landscape snapshot of eportfolio practice and technologies across Irish Higher Education Institutes (HEI). There is 
anecdotal evidence from the Eportfolio Ireland professional learning community that Irish eportfolio practice has been growing over the past three years across higher education (Farrell, Buckley, Donaldson, Uí Choistealbha, 2019). However, there is no empirical evidence about how Irish HEIs engage and adopt eportfolio in practice, and what technologies support the implementation of same. The aim of this study was to address this gap in the literature through a survey of the landscape of eportfolio practice at HEIs in Ireland and to examine eportfolio practice and technologies across Irish Higher Education. This research is expected to inform the development of future directions in eportfolio practice in higher education both nationally and internationally.

\section{What does the literature say?}

In this section, we examine contexts from the literature on Irish and international eportfolio practice in higher education and factors which influence eportfolio implementation and adoption. In this study we adopt a learning oriented definition of eportfolio rather than a technocentric one and define eportfolio as

"a vehicle for bringing together judiciously selected samples of students' work and achievements inside and outside the classroom for authentic assessment over time. A typical learning portfolio may include both academic materials and personal profiles and may designate some of its contents as public or private. The learning portfolio, then, becomes more than a product, a simple repository of artefacts; it becomes a process of reflection, of organizing, prioritizing, analysing, and communicating one's work and its value, which may prompt insights and goals" (Corley \& Zubizarreta, p.65).

\subsection{Eportfolio in higher education}

Portfolios have featured as part of the higher education landscape since the 1970s, initially in teacher education and English composition and becoming electronic in the 1990s before eventually going mainstream in the 2010s (Farrell, 2020). In higher education, portfolios were initially used as an assessment approach but evolved to encompass documenting student nonformal learning such as study abroad experiences, to support academic advising, to collect evidence of graduate attributes, and to document professional learning (Costelloe, 2021; Eynon \& Gambino 2017; Farrell, 2018; Baines \& Wilson 2018; Von Kronsky \& Oliver 2012). Eportfolio assessment itself has evolved from a modular to a programmatic approach, and as a capstone culminating experience at the end of a degree (Buente et al. 2015; Baird et al. 2016).

The literature evidences the positive impact of eportfolio on student learning and the learning experiences of professionals. The research suggests that eportfolio assessment enables students to integrate their learning and make connections between modules in an authentic way (Buente et al. 2015; Eynon \& Gambino 2017; Morreale et al. 2017). Studies indicate that eportfolio can support the development of critical thinking, self-regulation and reflective practice in students (Farrell \& Seery, 2019; McManus, 2021; Gallen, 2021; Ziegelbauer \& D'Errico, 2021). A recognition of the improved evidence base for eportfolio practice was the inclusion by the 
Association of American Colleges and Universities (AAC\&U) of eportfolio as a high impact practice which "denote institutionally-structured student experiences inside or outside of the classroom that are associated with elevated performance across multiple engagement activities and desired outcomes" (Watson et al. 2016, p. 65).

The Covid-19 pandemic has accelerated the adoption of alternative assessment approaches such as eportfolio in higher education, as due to the pivot online, campus based exams were no longer possible (Bozkurt, et. al., 2020; Farrell, 2020). The long-term impact of this change in assessment approaches has yet to be seen, but the pandemic may potentially be a catalyst for greater integration of eportfolio practices across higher education.

\subsection{Eportfolio in Ireland}

In Ireland, the pace of higher education adoption of eportfolio was slower than in the U.S, Australia and the UK (Farrell, 2018). This slower pace of adoption in Ireland was due to a number of factors: a lack of enabling national policy, an absence of a community of practice and a dearth of funding for research on higher education pedagogy and practice (Farrell, 2018; Nagle, O’Connell, Farrelly, 2019; Poole, Brown, McNamara, O’Hara, O’Brien, Burns, 2018).

One of the reasons for the growth of eportfolio practice in Irish higher education over the past five years is the emergence of an Irish eportfolio community called Eportfolio Ireland. Eportfolio Ireland was established in 2017 as a practitioner-led professional learning network with the aim of sharing and developing eportfolio research and practice in Irish higher and further education (Donaldson, Buckley, Farrell, Uí Choistealbha, 2018). Eportfolio Ireland holds professional development events and workshops which aim to support those interested in eportfolio research and practice. The community has co-created eportfolio resources including rubrics and ebooks to share and promote practice. This community of practice has connected Irish eportfolio practitioners with colleagues across Australia, Canada, and the United States through partnerships with Eportfolios Australia and the Association for Authentic, Experiential and Evidence Based Learning (AAEEBL) leading to a global sharing of knowledge and expertise.

On foot of the Irish National Forum for Enhancement of Teaching and Learning funding in 2015, the Eportfoliohub funded project produced three reports that drew on surveys from students, faculty and employers respectively (eportfoliohub.ie n.d. (a); eportfoliohub.ie n.d. (b) and eportfoliohub.ie n.d. (c)). Prior to 2017, there was a lack of published empirical research on eportfolio in Ireland. An ERIC search retrieved only seven journal articles. However since 2017, a number of articles from the Eportfolio Ireland community have been published on a range of topics such as eportfolio assessment (Donaldson, 2018; Hegarty, 2017), on learning portfolio (Farrell \& Seery, 2019), on the eportfolio literature (Farrell, 2018; Scully, O’Leary, Brown, 2018) on eportfolio professional learning (Donaldson, Buckley, Farrell, Ui Choistealbha, 2018), on teacher education (Uí Choistealbha, Mullally, McMorrough, 2018), on institutional implementation (Nagle, O'Connell, Farrelly, 2019), and on the history of portfolio research and practice (Farrell, 2020). This publication trend indicates that the Eportfolio Ireland professional learning network is having an impact on the 
eportfolio research and practice culture in Ireland. This trend is further evidenced by the special issue on eportfolio in the Irish Journal of Technology Enhanced Learning edited by the Eportfolio Ireland steering group, that this article is included within.

\subsection{Institutional adoption of eportfolio}

The literature on institutional adoption of eportfolio reveals a complex and challenging implementation process for higher education institutions which encompasses both pedagogical and technical elements. As Blevins and Brill (2017, p.223) state "a universitywide ePortfolio implementation is a complex undertaking that requires the long-term and attentive coordination of infrastructure, resources, and people".

For higher education institutions, there a number of drivers for introducing eportfolio such as curriculum reimagination, the requirement from professional bodies for accreditation, as a means of innovating assessment approaches, to support student placement, to integrate reflective practice into the student learning experience and to support professional development for academic and professional staff (Blevins \& Brill, 2017; Egan et al, 2018; Farrell, 2020; Nagle, O’Connell, Farrelly, 2019).

Roger's diffusion of innovation model which describes technology adoption over time underpins many of the approaches to eportfolio implementation (Stevens 2020; Blevins \& Brill 2017; Reynold \& Pirie, 2016). The literature on eportfolio implementation indicates that there are four main approaches to eportfolio implementation in higher education institutions: Bottom-up, top-down, technology-driven, middle-tier (Stevens, 2020), see table 1. below.

\begin{tabular}{|l|l|}
\hline Implementation approach & Aspects \\
\hline Bottom-up & $\begin{array}{l}\text { A bottom-up approach is organic and is usually driven by } \\
\text { staff in the form of early adopters who diffuse the eportfolio } \\
\text { innovation and practice through the institution. }\end{array}$ \\
\hline Top-down & $\begin{array}{l}\text { This approach is led by the institution's senior management } \\
\text { and is part of the strategic plan, it is a formal mandated } \\
\text { programme. }\end{array}$ \\
\hline Technology-driven & $\begin{array}{l}\text { This approach centres around the acquisition of an eportfolio } \\
\text { platform and may involve consultation with stakeholders, user } \\
\text { testing and needs analysis phases. }\end{array}$ \\
\hline Middle-tier & $\begin{array}{l}\text { In the middle-tier approach, champions in schools and } \\
\text { faculties lead the initiative. }\end{array}$ \\
\hline
\end{tabular}

Table 1. Eportfolio implementation approaches, adapted from Stevens (2020) 
Blevins \& Brill's (2017) eportfolio implementation framework is a very comprehensive evidence based approach to how institutions, faculties and schools can integrate eportfolio into their curricula, see figure 1 . below.

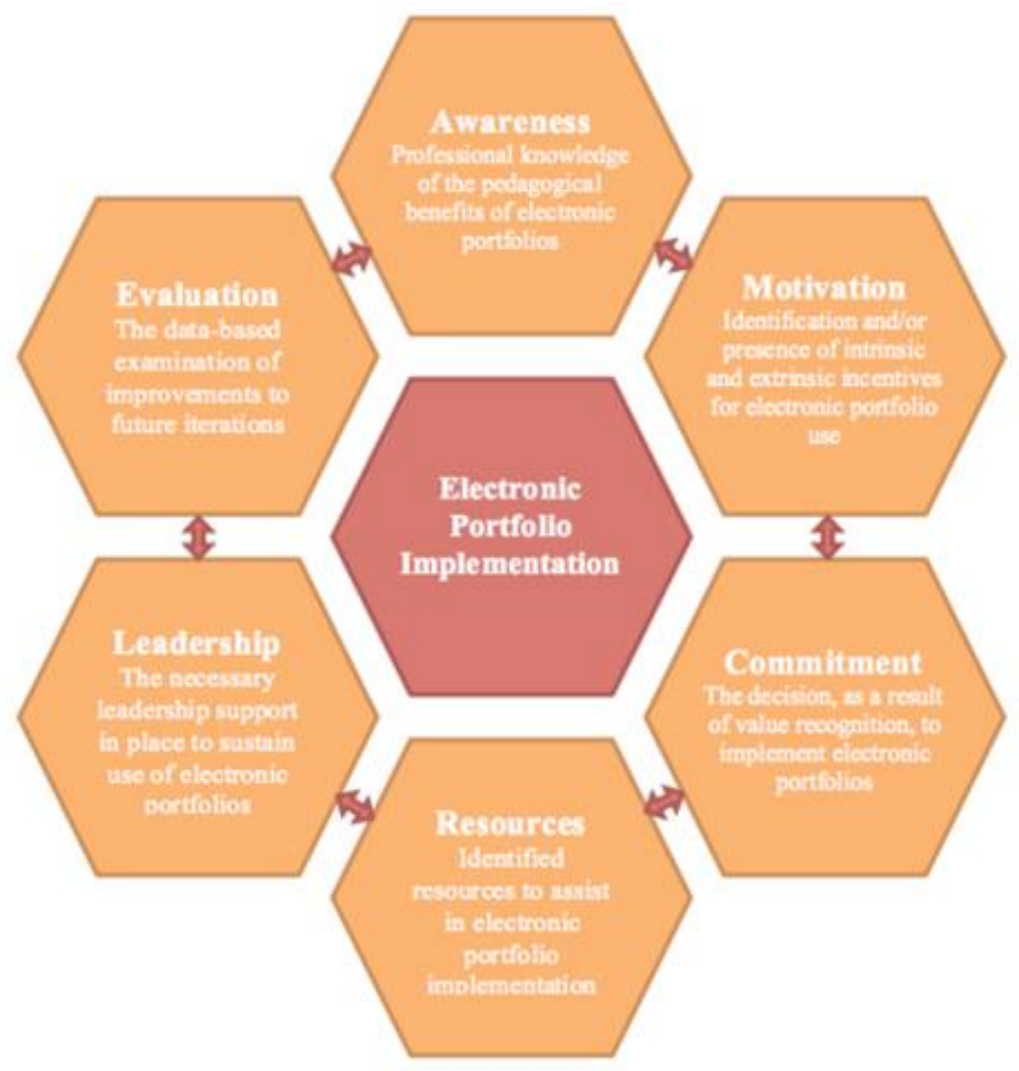

Figure 1. Blevins and Brill (2017) Eportfolio Implementation Framework, reproduced with permission.

The framework encompasses six components which take into account the human, leadership, pedagogical, technological, financial and support aspects which are key to a successful eportfolio implementation. The framework outlines six key aspects: awareness, motivation, commitment, resources, leadership, and evaluation as ingredients to support an institutional implementation programme (Blevins and Brill, 2017). This framework could be very useful to Irish higher education institutions in their planning and implementation of eportfolio, as "many factors still remain to deter HEIs from integrating eportfolios into their teaching" (Nagle, O'Connell, Farrelly, 2019, p.330) and like the introduction of any pedagogical innovation the implementation of eportfolio at scale can be very challenging (Cambridge, 2012; Eynon \& Gambino, 2017).

The literature on implementation has well documented the challenges institutions face when introducing eportfolio at scale. They include a lack of financial and human resourcing, a lack of awareness of the benefits of eportfolio, a lack of strategic direction, a lack of confidence in their digital competencies by staff and students, and challenges with the functionality and reliability of the technology underpinning eportfolio (Blevins and Brill, 2017; Coffey \& Ashford-Rowe, 2014; Fallowfield et al, 2019; Hallam et al, 2010; Holt et. al., 2016; Nagle, 
O’Connell, Farrelly, 2019; Reynolds, Pirie, 2016). Many institutional implementations do not succeed, as Blevins \& Brill (2017, p.219) observe:

"Significant costs associated with wide-scale integration efforts, such as organizationwide ePortfolio initiatives, certainly warrant concern if investments are not yielding positive and sustainable results. Recall that $42 \%$ of respondents in this study chose to abandon ePortfolio use".

Factors which can enable institutional implementation are symbiotic with the challenges discussed above. Adopting a structured approach such as the Blevins and Brill (2017) implementation framework would be beneficial to institutional implementation. It is crucial that eportfolio are fully integrated into the curriculum including technical and pedagogical supports (Egan et. al, 2018). The key factors influencing institutional adoption of eportfolio distilled from the literature are:

- Usable and flexible institutional platform

- Staff and leadership buy-in

- Technical and pedagogical support and professional development

- An institutional strategic vision for eportfolio

- Time and space for innovation (Blevins and Brill, 2017; Coffey \& Ashford-Rowe, 2014; Fallowfield et al, 2019; Hallam et al, 2010; Holt et. al., 2016; Nagle, O’Connell, Farrelly, 2019; Reynolds, Pirie, 2016).

\section{Methodology}

The study adopts a convergent parallel mixed methods design (Creswell, 2014) using qualitative and quantitative methods of inquiry. The study is framed by the following overarching research questions:

RQ1: What are the features of eportfolio practice in Irish higher education?

RQ2: What are the experiences of Irish higher education practitioners in adopting eportfolio?

Ethical approval for this research project was obtained from the DCU Research ethics committee (DCUREC/2019/136). Data was collected using an anonymous online survey, administered over two cycles: November 2019 and November 2020. The survey was adapted from the Australian eportfolio project (2010) instrument. It included open-ended and fivepoint Likert style scale questions about the features of eportfolio practice in higher education. Qualitative and quantitative data was collected via the questionnaire. The online survey was created using DCU hosted Google form and was administered through a recruitment email sent to participants. 
Participants were invited using a variety of specific sources: targeting staff from Irish higher education institutions and using publicly available contact details such as the National Forum listing of Teaching Associates, members of the Irish Learning Technology Association open LinkedIn group and through the All Ireland Society for Higher Education Newsletter. In addition, potential participants were approached via email from a generic Eportfolio Ireland email account with the plain language statement attached inviting them to participate. In total, 79 people consented to participate in the study, 59 in the first data collection cycle and 20 in the second cycle.

The qualitative data was analysed following a data-led approach following the Braun \& Clarke (2006) six phases of thematic analysis. The quantitative data was analysed using Microsoft Excel. Following the analysis of the qualitative and quantitative data sets, they were then compared using a side-by-side comparison approach (Creswell, 2014). In keeping with this approach the quantitative and qualitative data are interspersed as appropriate, rather than presenting them as distinct sets.

\section{Findings}

In this findings section, the qualitative and quantitative data from the questionnaire data sets are reported concurrently and presented thematically.

Seventy-nine participants responded to the questionnaire, representing staff from a range of Irish higher and further education institutions, see table 2. below

\begin{tabular}{|l|l|}
\hline Institution type & No. of responses \\
\hline University & 37 \\
\hline Institute of Technology & 17 \\
\hline Further education & 8 \\
\hline Private college & 10 \\
\hline Not specified & 7 \\
\hline Total & 79 \\
\hline
\end{tabular}

Table 2: Respondent profile by institution type

Four themes were constructed through the analytic process:

1. Institutional engagement with eportfolio

2. Technology underpinning eportfolio practice

3. Enablers of eportfolio adoption

4. Barriers to eportfolio adoption

These are reported in detail in the next section. 


\subsection{Institutional engagement with eportfolio}

The majority of Irish institutional engagement with eportfolio reported by respondents was at programme and module level to support student centred teaching and learning activities. When asked about how eportfolio were utilised in their institutions, $10.1 \%$ of respondents answered institution-wide, $31.9 \%$ of respondents answered at programme level and $31.9 \%$ of respondents answered at module level, see figure 2. below.

\section{Institutional engagement with eportfolio}

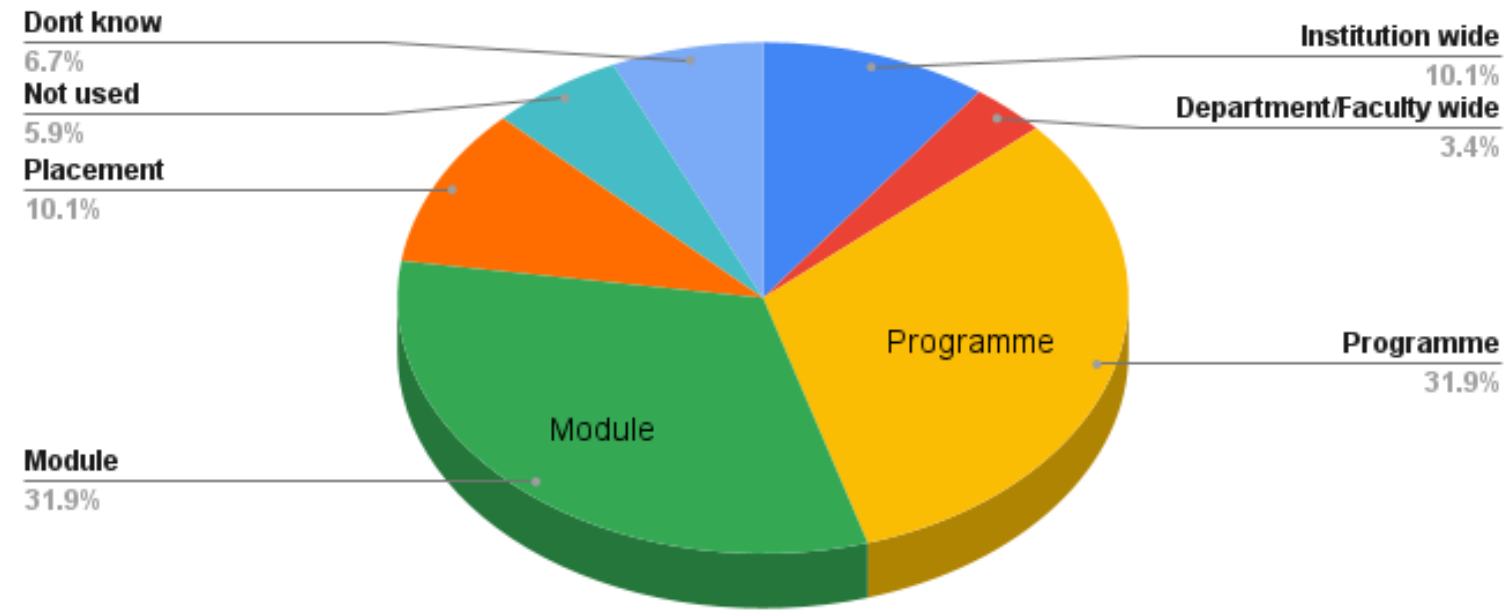

Figure 2. Institutional engagement with eportfolio

\section{Institutional leadership for eportfolio implementation}

When asked who leads the implementation of eportfolio at their institution, the majority of respondents (34.6\%) answered that their teaching and learning centre managed the implementation of eportfolio, while $32.7 \%$ of respondents reported that individual eportfolio champions led the implementation of eportfolio in their institution, and $11.5 \%$ of respondents reported that the institutional information technology services led the implementation of eportfolio, see figure 3 . below 


\section{Who manages the implementation of eportfolio in your institution?}

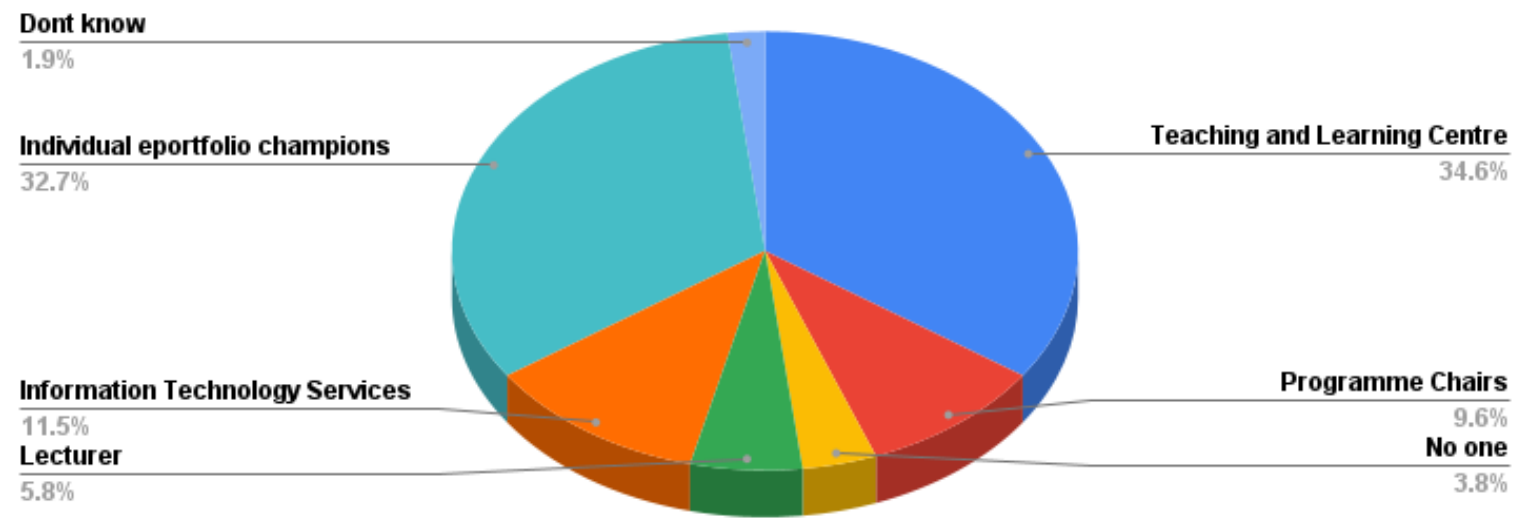

Figure 3. Leadership of eportfolio implementation

\section{Pace of institutional eportfolio adoption}

When asked to rate their institution's level of eportfolio adoption based on the Catalyst for Learning eportfolio adoption scale (Eynon \& Gambino, 2017). The majority of respondents $(46.8 \%)$ answered that their institution was at stage 1 of eportfolio adoption, therefore at the early stages of adoption. A further quarter of respondents $(25.3 \%)$ reported that their institution was at stage 3 of eportfolio adoption, therefore at more advanced stages but not yet at scale, see table 3. below:

\begin{tabular}{|l|l|}
\hline Level of Adoption & Responses \\
\hline $\begin{array}{l}\text { Stage 1: Emerging unsophisticated } \\
\text { eportfolio use in pockets }\end{array}$ & $46.8 \%$ \\
\hline $\begin{array}{l}\text { Stage 2: Emerging unsophisticated } \\
\text { eportfolio use at larger scale }\end{array}$ & $17.7 \%$ \\
\hline $\begin{array}{l}\text { Stage 3: Emerging sophisticated eportfolio } \\
\text { use in pockets }\end{array}$ & $25.3 \%$ \\
\hline $\begin{array}{l}\text { Stage 4: Emerging sophisticated eportfolio } \\
\text { use at larger scale }\end{array}$ & $10.1 \%$ \\
\hline
\end{tabular}

Table 3. Institutional levels of eportfolio adoption adapted from Eynon \& Gambino, 2017 


\section{Purpose and usage of eportfolio}

In Irish higher education institutions, eportfolio are mainly used for purposes of assessment, reflective learning, and placement/employability in their student context. When asked about how eportfolio were used in their student context, $24.2 \%$ of respondents answered for assessment purposes, $23.8 \%$ of respondents answered for reflective learning purposes, $11.7 \%$ of respondents answered for work placement purposes, and $11.3 \%$ of respondents answered for employability purposes, see figure 4 . below.

\section{Purpose and usage of eportfolio}

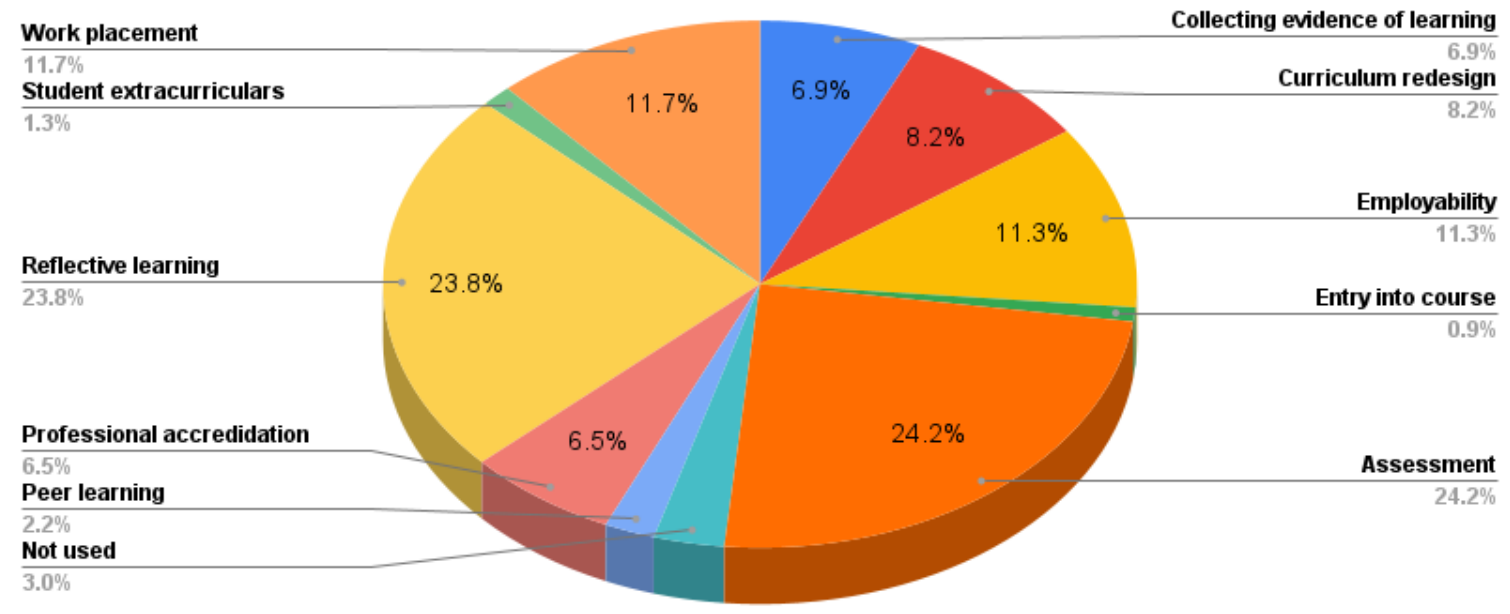

\section{Figure 4. Purposes and usage of eportfolio}

When asked about how eportfolio were used in their staff context, 59\% of respondents reported for the purpose of teaching and learning, $28.2 \%$ of respondents answered that eportfolio were used for staff professional development and $10.3 \%$ of respondents reported that eportfolio were not used, see figure 5. below. 


\section{Staff use of eportfolio}

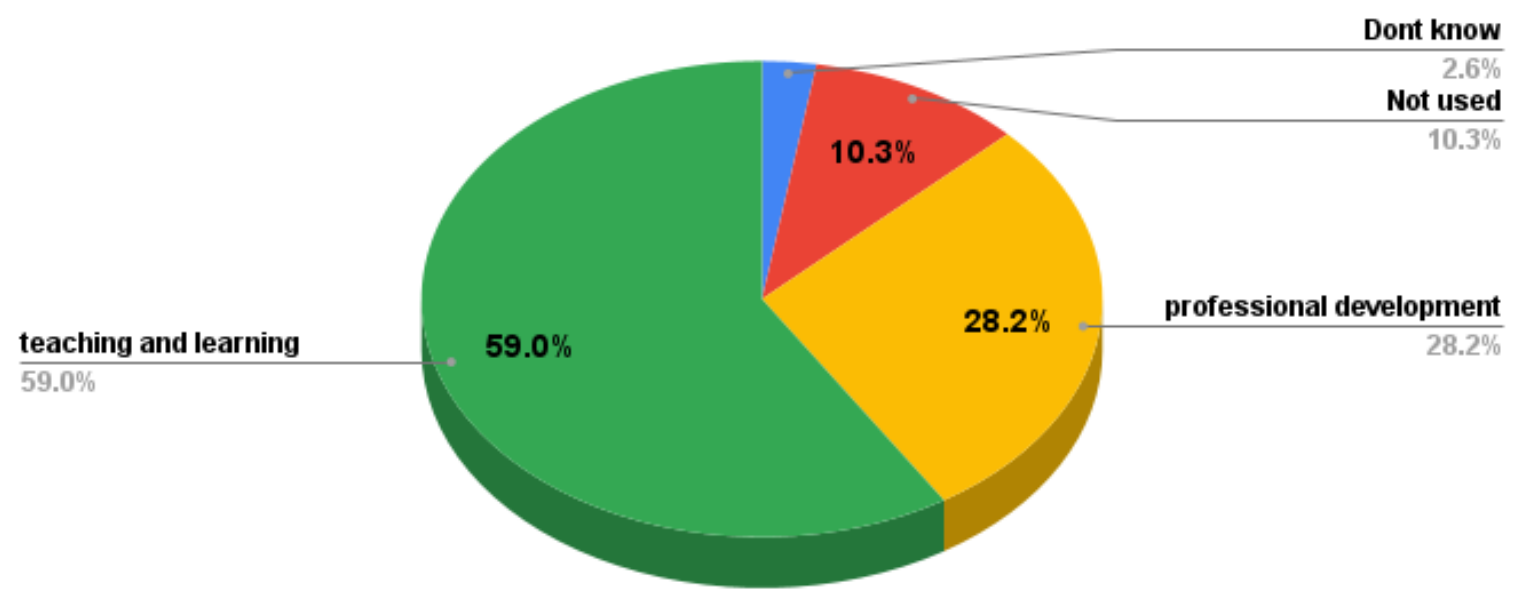

Figure 5. Staff use of eportfolio

\section{Impact of eportfolio}

According to respondents, the majority of institutions (92\%) have not evaluated the impact of eportfolio in their context. When asked about the impact of eportfolio in their context, participants reported impact in three areas as illustrated by the following quotes:

1. An improved student learning experience - "They have enhanced my students' learning and also my own. I have collected data about my students use of online diaries as opposed to eportfolios and the data has shown an improvement in their learning, in turn this has influenced the assessment strategy adopted"

2. Opportunities for reflective learning - "More reflective practice, peer-to-peer learning, up-skilling of staff and students, showcasing of work".

3. Creating an institutional culture of innovative assessment - "Innovation in assessment; Increased engagement in assessment for learner and lecturer; Greater flexibility in assessment approaches; Contributes toward achieving 360-degree feedback".

\subsection{Technology underpinning eportfolio practice}

A wide range of platforms used to underpin eportfolio were reported by respondents, this comprised a mix of eportfolio specific platforms, virtual learning environments (VLE), web based blogging and website platforms and office platforms, see table 4 . below. 


\begin{tabular}{|l|l|}
\hline \multicolumn{2}{|c|}{ Types of eportfolio platform used } \\
\hline Eportfolio specific platform & Mahara, Pebblepad, Pathbrite, CourseNetworking (CN) \\
\hline Virtual learning environment (VLE) & Blackboard, Brightspace, Moodle \\
\hline Website and blogging platforms & Wix, Weebly, Wordpress, Livebinders, Behance \\
\hline Office platforms & Microsoft OneNote and Sway, G-suite \\
\hline Other & Seesaw \\
\hline
\end{tabular}

Table 4. Types of eportfolio platform used

When asked about the technology underpinning institutional eportfolio practice, $33.7 \%$ of respondents reported that they used Mahara, 15.2\% reported that they used blogging and website platforms such as Wordpress, $15.1 \%$ reported using Office platforms and $12.8 \%$ reported using virtual learning environments.

\subsection{Enablers of eportfolio adoption}

A number of themes related to the factors which enabled institutions to successfully implement eportfolio were reported in the data. Three themes related to enablers of eportfolio adoption were identified in the data:

1. Professional development and support

2. Buy-in

3. The impact of eportfolio champions

\section{Professional development and support}

The provision of both formal and informal professional development and pedagogical and technical support centrally by institutions was found to be a key enabler for successful institutional eportfolio adoption.

"CPD provided by the e-learning unit, individual champions and in one case a departmental initiative"

When asked about the nature of support for eportfolio practice provided by their institution, $28.7 \%$ of respondents reported that workshop or drop in clinics were provided, $28.7 \%$ that online resources to support eportfolio practice were provided, $20 \%$ reported that their institution provided dedicated support staff for eportfolio, $15.7 \%$ reported that no support for eportfolio was provided by their institution. See figure 6 . below. 


\section{What support is provided to users of the eportfolio in your context?}

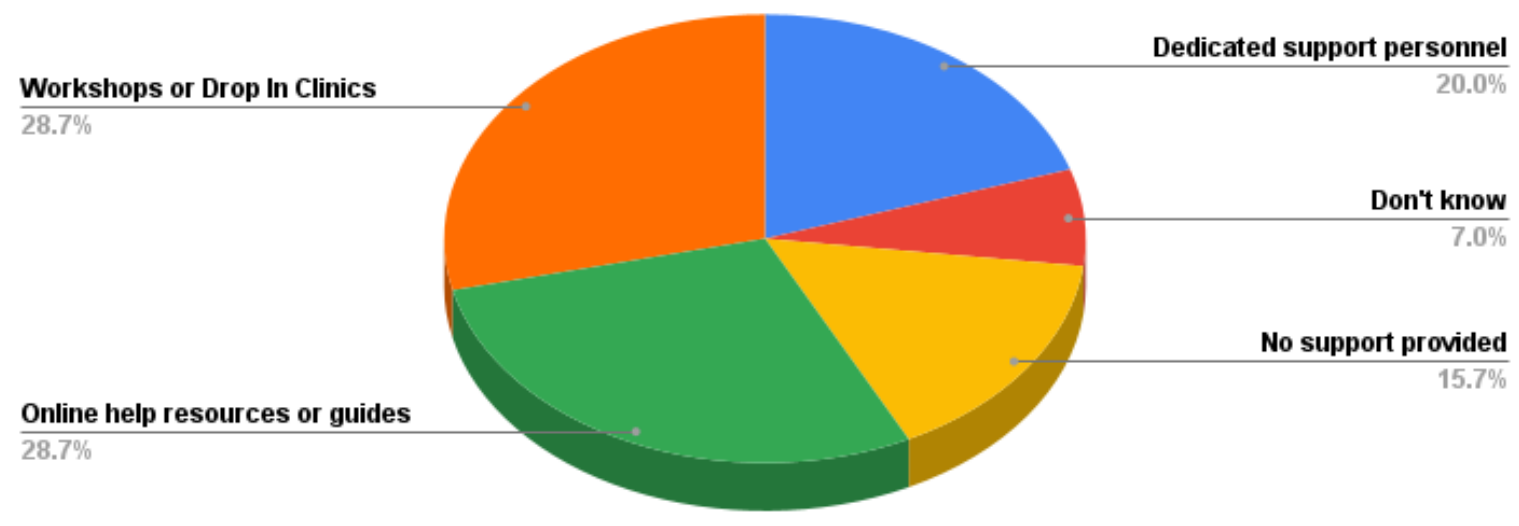

Figure 6. Provision of eportfolio support

Buy-in

The presence of support and buy-in for the implementation of eportfolio was identified by participants as a key ingredient for success, in particular senior management support, programme level coordination and support and commitment by lecturers to implementing an eportfolio approach.

"establishing the value for all stakeholders - students, staff, Schools; time and resource allocation need full consideration and follow-through"

When asked if eportfolio was a strategic priority in their institution, a majority of respondents $(50.6 \%)$ answered no, $33.8 \%$ answered yes and $15.6 \%$ did not know.

\section{The impact of eportfolio champions}

Eportfolio champions were identified by participants as enablers of successful eportfolio implementation. Champions were typically internal academic colleagues who shared and showcased their eportfolio practice which served to spread and model best practice institutionally.

"Staff willing to innovate and become internal champions"

\subsection{Barriers to eportfolio adoption}

A number of themes related to factors which are barriers to institutional adoption of eportfolio were identified in the data. Four themes were constructed through the analytic process related to barriers to eportfolio adoption: 
1. Academic workload

2. Lack of support

3. Absence of institutional buy-in

4. Lack of awareness about eportfolio

\section{Academic workload}

Participants reported that the additional workload associated with trying out a new pedagogical approach on top of their existing teaching, research and service workload was a barrier to eportfolio adoption.

"High workload already and little support that provides people with the opportunity to try new things".

\section{Lack of support}

A lack of technical and pedagogical support as well as the absence of an institutional eportfolio platform were reported by participants as barriers to eportfolio adoption.

"lack of learning technologist support lexpertise in eportfolio"

\section{Absence of institutional buy-in}

Participants reported that an absence of institutional buy-in; no institutional strategy, no financial support and a lack of senior management support were barriers to eportfolio adoption.

"A lack of direction and a lack of example from Heads of School and Senior

Management in relation to the adoption and use of eportfolios by staff and students".

\section{Lack of awareness about eportfolio}

A lack of awareness of the affordances of eportfolio by staff and students was also reported by participants as a barrier to adoption.

"generalised lack of knowledge of eportfolios among staff, a lack of awareness among students of the concept of eportfolios and their use and value" 


\section{Discussion}

The purpose of this study was to explore how Irish higher education institutions engage with and adopt eportfolio in practice. This section discusses the findings of the study in relation to the research questions for the study and the existing literature on eportfolio practice and adoption.

\section{RQ1: What are the features of eportfolio practice in Irish higher education?}

In relation to practice there are three broad features evident from the data: (i) teaching staffs' use with their students; (ii) staff use for their own purposes and (iii) lack of evaluation. With respect to the ways that teaching staff use eportfolios with their students the findings indicate that Irish eportfolio practice mainly centred on using eportfolio for student assessment, reflection, to support placement experiences and to develop student employability skills. This is consistent with previous research which found that the majority of higher education eportfolio practice centres around assessment, placement and to collect evidence of graduate attributes (eportfoliohub n.d. (b); Von Kronsky \& Oliver 2012; Eynon \& Gambino 2017; Farrell, 2018; Baines \& Wilson 2018).

While the predominant feature of use involves their employment by staff to support students, there was also evidence that staff are using eportfolios for personal and/or professional purposes. Given the increasing importance of demonstrable career development for those who teach such as the development of the National Forums' Professional Development framework (National Forum, 2016), eportfolios are well placed to provide a means of mapping and evidencing this process.

Given the emphasis on the need for evidence-informed practice as a way of improving teaching and learning it is particularly noteworthy that hardly anyone in the study reported evaluating their eportfolio practice. As we previously acknowledged, there has been an increase in the numbers of papers published in recent years on the topic. However, while eportfolios do present a number of opportunities and benefits for students, staff and institutions these need to be researched and reported on if they are to become more widely used (Bryant \& Chittum, 2013).

\section{RQ2: What are the experiences of Irish higher education institutions with adopting eportfolio?}

The findings of this study indicate that the implementation and adoption of eportfolio by Irish HEIs has been quite uneven, the majority of institutions were reported to be at early stages of adoption. The majority of eportfolio practice was reported to be at module or programme level, our study found very few examples of eportfolio adoption at an institution wide stage. 
The study indicated that there is quite an extensive range of platforms used, from proprietary VLEs to open source solutions. The range of potential uses and roles is one of the strengths of eportfolios (Kunnari \& Laurikainen, 2017; Scully, O'Leary \& Brown 2018). However, given the multiplicity of roles and the ever increasing cybersecurity and digital wellbeing concerns one might question whether (in the future) one institutional eportfolio platform can meet the diverse needs and requirements of staff, learners, potential employers, accreditation bodies and institutional quality assurance procedures.

The data revealed a number of factors which enabled institutions to successfully implement eportfolio: (i) professional development and support (ii) buy-in and (iii) the impact of eportfolio champions. The provision of both formal and informal professional development and pedagogical and technical support centrally by institutions was found to be a key enabler for successful institutional eportfolio adoption. This finding is well supported by previous studies on implementation (Blevins and Brill, 2017; Egan et al, 2018).

This study found that buy-in and championing at the macro level of senior management, the meso level of schools/departments and the micro level of programmes and modules was a key ingredient for successful eportfolio implementation. This finding is well supported in the literature which identifies an institutional strategic vision for eportfolio and staff and leadership support as crucial to successful eportfolio implementation (Blevins and Brill, 2017; Coffey \& Ashford-Rowe, 2014; Fallowfield et al, 2019; Hallam et al, 2010; Holt et. al., 2016; Nagle, O'Connell, Farrelly, 2019; Reynolds, Pirie, 2016). The role of champions in the promulgation of educational technology responses is well documented (Eynon \& Gambino, 2017); however, if eportfolios are to enjoy a wider level of use and acceptance, the use of champions (however enthusiastic) is not sustainable in the longer term. It may be more advantageous to spread the advocacy of eportfolio practice across faculties and schools. If the pandemic and ensuing lockdown has highlighted anything it is the fragility of the college ecosystem. The technical infrastructure that facilitates eportfolios is certainly crucial, but so too are the necessary policies and procedures that sustain and nurture the central core of institutions - its people.

The data revealed four barriers to Irish institutional eportfolio adoption: (i) academic workload (ii) lack of support (iii) absence of institutional buy-in (iv) lack of awareness about eportfolio. These findings are symbiotic with the enablers discussed above. The second cycle of this study took place during the Covid-19 pandemic when academic workload was certainly keenly felt and may well have impacted on eportfolio adoption. It is well documented in the literature that implementation of eportfolio at institutional level is very challenging and many eportfolio initiatives fail (Blevins and Brill, 2017; Cambridge, 2012; Eynon \& Gambino, 2017).

In summary, what has emerged from this study as landscape snapshot of current eportfolio practice and adoption is: 
1. Irish eportfolio practice is mainly centred on using eportfolio for student assessment, reflection, to support placement experiences and to develop student employability skills.

2. Teaching staff are beginning to use eportfolio to document their professional practice and learning.

3. The majority of Irish eportfolio practice is not being evaluated.

4. A strategic approach to eportfolio implementation is necessary.

5. Institutional eportfolio initiatives need to be underpinned with adequate financial, human, technical and pedagogical resources and support.

\section{Conclusions}

The purpose of this study was to explore eportfolio practice and adoption across Irish Higher Education Institutes. The findings of this study indicate that if Irish HEIs want to scale up eportfolio practice to an institution-wide approach a far more strategic vision is needed. This study recommends that underpinning a strategic eportfolio implementation should be adequate financial, human, technical and pedagogical resources and support. A key finding from this study was that many Irish HEIs had not evaluated their eportfolio practice. A further recommendation is in order to understand current eportfolio practices, institutions should evaluate their current eportfolio practices and use this to inform a strategic approach to scaling up institutional eportfolio practice. Future research is planned to do a qualitative study to further explore Irish eportfolio practitioners and institutional leaders' experiences of eportfolio adoption/non-adoption and the impact of the Covid-19 pandemic on assessment practices. We are very mindful that one of the limitations was that the student voice was not captured and while we contend that the participants surveyed are well placed to provide insight into their respective institution's practice they necessarily provide only one side of the story. 


\section{References}

Baines, K and Wilson, K. (2018). From Berlin to Belize. In: Eynon, B and Gambino, L (eds.), Catalyst in action. Stylus, Virginia.

Baird, K, Gamble, J and Sidebotham, M. 2016. Assessment of the quality and applicability of an eportfolio capstone assessment item with a bachelor of midwifery program. Nurse Education in Practice, 20: 11-16. DOI: https://doi.org/10.1016/j.nepr.2016.06.007

Blevins, S., Brill, J., (2017). Enabling Systemic Change: Creating an ePortfolio Implementation Framework Through Design and Development Research for use by Higher Education Professionals. International Journal of Teaching and Learning in Higher Education, 29(2).

Bozkurt, A., Jung, I., Xiao, J., Vladimirschi, V., Schuwer, R., Egorov, G., Lambert, S., AlFreih, M., Pete, J., Olcott, Jr., D., Rodes, V., Aranciaga, I., Bali, M., Alvarez, A. J., Roberts, J., Pazurek, A., Raffaghelli, J. E., Panagiotou, N., de Coëtlogon, P., Shahadu, S., Brown, M., Asino, T. I., Tumwesige, J., Ramírez Reyes, T., Barrios Ipenza, E., Ossiannilsson, E., Bond, M., Belhamel, K., Irvine, V., Sharma, R. C., Adam, T., Janssen, B., Sklyarova, T., Olcott, N., Ambrosino, A., Lazou, C., Mocquet, B., Mano, M., \& Paskevicius, M. (2020). A global outlook to the interruption of education due to COVID-19 pandemic: Navigating in a time of uncertainty and crisis. Asian Journal of Distance Education, 15(1), 1-126. Retrieved from http://www.asianjde.com/ojs/index.php/AsianJDE/article/view/462

Bryant, L., Chittum, J. (2013). Eportfolio Effectiveness: A(n Ill-fated) Search for Empirical Support. International Journal of Eportfolio, 3(2), 189-198. Retrieved from http://www.theijep.com/

Buente, W, Winter, JS, Kramer, H, Dalisay, F, Hill, YZ and Buskirk, PA. 2015. Program based assessment of capstone eportfolios for a communication BA curriculum. International Journal of ePortfolio, 5(2): 169-179.

Cambridge, D. (2012). Preface. In D. Cambridge (Ed.), E-portfolios and global diffusion: Solutions for collaborative education (pp. xi-xvi). Washington, DC: IGI Global

Coffey, U., \& Ashford-Rowe, K. (2014). The changing landscape of ePortfolios: A case study in one Australian university. Australasian Journal of Educational Technology, 30(3). https://doi.org/10.14742/ajet.199

Corley, C.R., Zubizarreta, J. (2012). The Power and Utility of Reflective Learning Portfolios in Honours. Journal of the National Collegiate Honours Council, 13(1), 63-76 Spr-Sum. Retrieved from https://digitalcommons.unl.edu 
Costelloe, L., (2021). Exploring the potential of digital teaching portfolios to support in/nonformal professional development for those who teach in Higher Education. Irish Journal of Technology Enhanced Learning, 6(1), 1-13. https://doi.org/10.22554/ijtel.v6i1.72

Creswell, J.W. (2014). Research Design: Qualitative, Quantitative and Mixed Methods Approaches. London: Sage.

Donaldson, L., Buckley, K., Farrell, O., Uí Choistealbha., J., (2018) Reflections on ePortfolio Professional Learning: Harnessing an Unconference Approach. AePR, 2 (3).

Donaldson, L. (2018) (Ed), Eportfolio Based Assessment - Inspiring Exploration and Supporting Evaluation for Practitioners. [online book]. National Institute for Digital Learning, Dublin City University.

Egan, J., Cooper-Ioelu, P., Spence, F., Petersen, M.L., (2018). The Curricular and Technological Nexus: Findings From a Study of ePortfolio Implementation. The International Journal of ePortfolio, 8(2).

Eportfoliohub (Undated) (a). Awareness and Usage of ePortfolios by Students in Higher Education in Ireland: Findings from a Student Survey. Eportfoliohub.ie. Available from: https://eportfoliohub.ie/wp-content/uploads/2016/08/Survey-Students-Report low.pdf [Accessed 23/05/2021].

Eportfoliohub (Undated) (b). Awareness and Usage of ePortfolios by Faculty in Higher Education in Ireland: Findings from a Faculty Survey. Eporftoliohub.ie. Available from: https://eportfoliohub.ie/wp-content/uploads/2016/08/Survey-Faculty-Report_low.pdf [Accessed 23/05/2021].

Eportfoliohub (Undated) C. Using ePortfolios for Recruitment: Employers' Perspectives. Eportfoliohub.ie. Available from: https://eportfoliohub.ie/wpcontent/uploads/2016/09/Survey-Employer-Report.pdf [Accessed 23/05/2021].

Eynon, B and Gambino, L. (2017). High impact eportfolio practice. Sterling, VA: Stylus Farrell, O., (2020). From Portafoglio to Eportfolio: The Evolution of Portfolio in Higher Education. Journal of Interactive Media in Education, 2020(1), p.19. DOI: http://doi.org/10.5334/jime.574

Farrell, O. 2018. Failure to launch: The unfulfilled promise of eportfolios in Irish higher education: An opinion piece. DBS Business Review, 2. DOI:

https://doi.org/10.22375/dbr.v2i0.30 
Farrell, O., \& Seery, A., (2018). "I am not simply learning and regurgitating information, I am also learning about myself": learning portfolio practice and online distance students. Distance Education, 40 (1). doi: 10.1080/01587919.2018.1553565

Fallowfield, S.M., Urtel, M., Swinford, R., Angermeier, L., Plopper, A., (2019). A Case Study in ePortfolio Implementation: A Department-Wide Perspective. The International Journal of ePortfolio, 9(2).

Gallen, J. (2021). Eportfolios as Reflective Assessment of Social Justice. Irish Journal of Technology Enhanced Learning, 6(1), 22-28. https://doi.org/10.22554/ijtel.v6i1.89

Hallam, G. \& Harper, W. \& McAllister, L. \& Hauville, K. Creagh, T. (2010). Australian ePortfolio Project. ePortfolio use by university students in Australia: Informing excellence in policy and practice. Supplementary report.

Hegarty, S. (2017). Integrating ePortfolios into an assessment strategy in an undergraduate Geography module, AePR, 2 (1).

Holt, D. M., McGuigan, N., Kavanagh, M., Leitch, S., Ngo, L., Salzman, S., Watty, K., \& McKay, J. (2016). Academic leaders' perspectives on adopting ePortfolios for developing and assessing professional capabilities in Australian business education. Australasian Journal of Educational Technology, 32(5). https://doi.org/10.14742/ajet.2666

McManus, R. (2021). Lessons from reflective journaling in undergraduate eportfolios. Irish Journal of Technology Enhanced Learning, 6(1), 29-36. https://doi.org/10.22554/ijtel.v6i1.81

Morreale, C, Van Zile-Tamsen, C, Emerson, CA and Herzog, M. 2017. Thinking skills by design: A capstone eportfolio to promote reflection, critical thinking and curriculum integration. International Journal of Eportfolio, 7(1), 13-28.

National Forum for the Advancement of Teaching and Learning in Higher Education (2016).

National Professional Development Framework for All Staff Who Teach in Higher

Education. National Forum for the Advancement of Teaching and Learning in Higher

Education. Available from https://hub.teachingandlearning.ie/resource/national-professionaldevelopment-framework-for-all-staff-who-teach-in-higher-education/ [Accessed 20/09/2021].

Nagle, L., O'Connell, M., Farrelly, T., (2019). A gap in governance: acknowledging the challenges of organic ePortfolio implementation. Educational Media International, 56(4). doi:10.1080/09523987.2019.1682271

Poole, P., Brown, M., McNamara, G., O’Hara, J., O’Brien, S., Burns, D., (2018). Challenges and supports towards the integration of ePortfolios in education. Lessons to be learned from Ireland. Heliyon 4 e00899.doi: 
10.1016/j.heliyon.2018.e00899https://doi.org/10.1016/j.heliyon.2018.e0089924058440/Ó2018

Von Kronsky, BR, Oliver, B. (2012). The iPortfolio: Measuring uptake and effective use of an institutional electronic portfolio in higher education. Australasian Journal of Educational Technology, 28(1): 67-90. DOI: https://doi.org/10.14742/ajet.884

Uí Choistealbha, J., Mullally, A., \& McMorrough, A. (2018). Moving from a focus on the student to a focus on the teacher. In I. Kunnari (ed.) Higher education perspectives on ePortfolios. HAMK Unlimited Journal 3.10.2018. Retrieved [23/1/2019] from https://unlimited.hamk.fi/ammatillinen-osaaminen-ja-opetus/focus-on-the-teacher

Reynolds, C. \& Pirie, M.S. (2016) Creating an Eportfolio Culture on Campus through Platform Selection and Implementation, Peer Review, vol. 18, no. 3, pp. 21-24.

Stevens, C., (2020). Institutional ePortfolio Implementation: A Review of Program Transformation. AePR, 3(2).

Scully, D., O’Leary, M. \& Brown, M. (2018). The Learning Portfolio in Higher Education: A Game of Snakes and Ladders. Dublin: Dublin City University, Centre for Assessment Research, Policy \& Practice in Education (CARPE) and National Institute for Digital Learning (NIDL).

Watson, CE, Kuh, G, Rhodes, T, Penny Light, T and Chen, H. (2016). Editorial: ePortfolios The eleventh high impact practice. International Journal of Eportfolio, 6(2): 65-68.

Ziegelbauer, C., \& D'Errico, B. (2021). ePortfolio in Teacher Education and Academic Further Education. Irish Journal of Technology Enhanced Learning, 6(1), 37-46. https://doi.org/10.22554/ijtel.v6i1.78 